\title{
PENGARUH TEKNIK PEMBELAJARAN PETA PIKIRAN (MIND MAP) BERBASIS PROBLEM SOLVING TERHADAP HASIL BELAJAR SISWA PADA MATERI POKOK FLUIDA DINAMIS DI KELAS XI SEMESTER II SMA NEGERI 11 MEDAN T.P 2014/2015
}

\author{
Rhodo Mauritz Efraim Siagian dan Togi Tampubolon \\ Jurusan Fisika FMIPA Universitas Negeri Medan \\ rhodo.siagian16@gmail.com
}

\begin{abstract}
ABSTRAK
Penelitian ini bertujuan untuk mengetahui pengaruh yang signifikan teknik pembelajaran peta pikiran (mind map) berbasis problem solving terhadap hasil belajar siswa pada materi pokok Fluida Dinamis. Jenis penelitian ini adalah quasi eksperimen. Populasi penelitian adalah seluruh siswa kelas XI SMA Negeri 11 Medan T.P 2014/2015 yang terdiri dari tujuh kelas paralel sebanyak 245 orang. Dengan teknik cluster random sampling terpilih kelas XI IA-1 sebagai kelas kontrol dan XI IA-2 sebagai kelas eksperimen. Instrumen yang digunakanadalah soal pilihan berganda sebanyak 20 soal yang telah dilakukan uji persyaratan tes untuk mengukur hasil belajar. Hasil penelitian menunjukkan rata-rata nilai pretes kelas eksperimen 40,48 dan kelas kontrol 42,58. Pada pengujian normalitas dan homogenitas kedua kelas diperoleh bahwa data kedua kelas berdistribusi normal dan homogen. Dari hasil uji beda nilai rata-rata kedua kelas untuk pretes

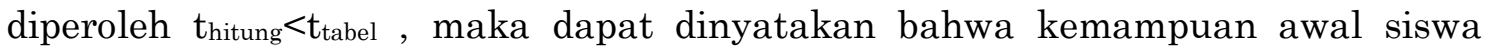
kedua kelas sampel sama. Kemudian diberi perlakuan yaitu kelas eksperimen denganteknik pembelajaran peta pikiran (mind map) berbasis problem solving dan kelas kontrol dengan pembelajaran langsung. Setelah pembelajaran selesai, dilakukan postes dengan hasil nilai rata-rata kelas eksperimen 75,16 dan kelas kontrol 66,13. Pada pengujian normalitas dan homogenitas diperoleh bahwa data postes berdistribusi normal dan variansnya homogen. Dari hasil uji beda nilai

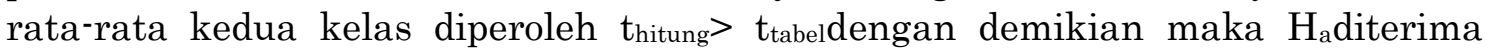
yang berartiada pengaruh yang signifikan penerapan teknik pembelajaran peta pikiran (mind map) berbasis problem solving terhadap hasil belajar siswa pada materi pokok Fluida Dinamis di kelas XI SMA Negeri 11 Medan T.P. 2014/2015.
\end{abstract}

Kata kunci : teknik pembelajaran peta pikiran (Mind Mapping), problem solving, fluida dinamis, hasil belajar

\section{ABSTRACT}

This research aims to understand the influence of significant learning technique maps the mind solving a problem based on student learning outcomes to the matter of basic dynamic of a fluid .A kind of this research is quasi experiment. The population in the research is all students in class xi consisting of seven class parallel as many as 245 people. With clusters of technique random sampling elected XI IA-1 class as a class control and XI IA-2 as a class experiment. An instrument used was all about the choice of worship of idols as many as 20 about who has undergone a test requirements to measure learning outcomes. The result showed average score pretes a class experiment 40,48 and grade control 42,58. On testing normality and homogeneity penultimate class obtained noting that the penultimate class normal distribution and homogeneous. The average value of test results of the second class to pretes obtained $t_{\text {count }}<t_{\text {table }}$, it can be stated that the 
same students second sample class early. Then were given treatment that is a class of his experiments with mind map of learning techniques (mind maps) based control with solving the problem directly and class of learning. After learning done , postes done with the average value of a class experiment 75.16 and 66.13 grade control. On testing of normality and homogeneity that the data obtained postes variance normal distribution and homogeneous. The average value of test results of the second class obtained $t_{\text {count }}>t_{\text {table }}$ with so then $H_{a}$ accepted that means there is a significant influence the implementation of the mind map of learning techniques (mind maps) based on the results of solving the problem of student learning in class subject matter of a fluid dynamic in SMAN 11 Medan T.P 2014/2015

Keywords : mind mapping, problem solving, fluid dynamic, learning outcomes

\section{PENDAHULUAN}

Sekolah merupakan salah satu lembaga yang dijadikan sebagai tempat berlangsungnya program pendidikan. Di sekolah terjadi kegiatan belajar mengajar antara peserta didik dengan guru. Interaksi yang terjadi antara peserta didik dan guru diharapkan mampu mengembangkan potensi yang dimiliki anak didik.Namun pada kenyataannya bahwa potensi serta hasil belajar siswa dalam bidang IPA khususnya fisika masih rendah. Yang harus diketahui yaitu mata pelajaran Fisika pada dasarnya adalah ilmu pengetahuan alam yang cukup menarik, karena mempelajari bagianbagian dari alam dan interaksi di dalamnya serta dapat diterangkan dengan konsep-konsep sederhana. Banyak siswa menganggap pelajaran Fisika sulit dan hanya bisa dipahami orang-orang jenius sajadan hal ini menjadi gambaran yang terlintas pertama kali dibenak siswa.

Berdasarkan hasil observasi peneliti pada siswa SMA Negeri 11 Medan berpendapat bahwa pelajaranFisika itusulit dipahami dan banyak siswa yang kurang menyukai pelajaran tersebut dan hasil wawancara menyatakan bahwa teknik pembelajaran yang cenderung terbatas.

Rendahnya hasil belajar siswa, khususnya pada mata pelajaran Fisika disebabkan oleh dua hal, yaitu:(1) siswa masih belum menyadari manfaat Fisika dalam kehidupannya; (2)banyak siswa yang beranggapan bahwa Fisika merupakan mata pelajaran hitungan.

Menyikapi masalah di atas, perlu adanya upaya yang dilakukan oleh guru untuk menggunakan teknik pembelajaran yang membuat siswa lebih tertarik dalam belajar. Kurangnya teknik pembelajaran yang benar dan efektif dalam menjalankan proses pembelajaran yang hanya terpaku pada materi dan hasil pembelajaran merupakan perhatian khusus bagi penulis untuk dilakukan suatu perubahan. Selama ini yang terjadi adalah ketika guru mengajar maka asumsi bahwa siswa akan belajar. Peta Pikiran (Mind Map) merupakan suatu teknik pembelajaran yang mengunakan fungsi kedua belahan otak yaitu otak kanan dan otak kiri, dalam pembelajaran Mind Map penggambaran-nya mengunakan garis, lambang, kata-kata, serta gambar sehingga mengoptimal-kan kerja otak, baik otak kanan maupun otak kiri. Teknik ini dapat membantu menciptakan proses belajar mengajar yang merangsang minat dan kemampuan imajinasi siswa.

Selain itu menurut Tony Buzan dalam Saleh (2008 : 76-85) menyatakan manfaat mind map dalam proses pembelajaran di kelas, yaitu sebagai berikut :1. Mind map untuk memilah; 2 . Mind map untuk mengingat; 3. Mind map untuk mencatat; 4. Mind map untuk memahami; 5. Mind map untuk berimajinasi; 6. Mind map untuk tetap 
berminat; 7. Mind map untuk mengendalikan; 8. Mind map untuk menjadi kreatif. Mind Map adalah sistem pembelajaran yang paling dipakai seluruh dunia. Sistem ini membantu untuk menggunakan potensi otaknya bertingkat-tingkat lebih tinggi dalam kegiatan berpikir dan belajar (Windura, 2008). Peta pembelajaran akan membantu mengembangkan kreativitas juga kemampuan analitis dan logika(Svantesson, 2004)

\section{METODE PENELITIAN}

Penelitian ini di laksanakan di SMA Negeri 11 Medan, mulai tanggal 20 April sampai 04 Mei 2015. Populasi penelitian ini adalah seluruh siswa kelas XI SMA Negeri 11 Medan yang berjumlah 7 kelas berjumlah 245 orang. Pengambilan sampel dilakukan secara cluster random sampling yaitu dari 7 kelas terpilih 2 kelas menjadi sampel penelitian. Kelas XI-IA1 sebagai kelas kontrol dan kelas XI-IA2 sebagai kelas eksperimen.

Jenis penelitian ini adalah quasi eksperimen yaitu penelitian yang di maksudkan untuk mengetahui ada tidaknya akibat dari suatu perlakuan yang di kenakan pada subjek siswa. Rancangan penelitian yang di gunakan merupakann rancangan uji awal dan akhir dari kelompok kontrol dan eksperimen. Langkah-langkah yang ditempuh dalam pelaksanaan penelitian adalah sebagai berikut:

a. Tahap persiapan: (1) Meminta izin kepada kepala sekolah SMA Negeri 11 Medan tentang kegiatan penelitian. (2) Melakukan wawancara pada guru Fisika di SMA Negeri 11 Medan. (3) Menentukan waktu penelitian (4) Menyiapkan alat pengumpulan data

b. Tahap pelaksanaan: (1) Memvalidasi tes/instrumen penelitian

Menentu-kan kelas sampel dari populasi yang ada (3) Melaksanakan pretes pada kedua kelas untuk mengetahui kemampuan awal siswa dan pengelompokan siswa sebelum sebelum materi diajarkan.

Melaksanakan pembelajaran kepada kedua kelas. Pada kelas eksperimen menggunakan teknik pembelajaran peta pikiran (mind map) berbasis problem solving dan kelas kontrol menggunakan model pembelajaran langsung. (5) Memberikan postes kepada kedua kelas untuk mengetahui hasil belajar.

c. Setelah uji hipotesis dapat diambil kesimpulan.

Teknik analisis data yang dilakukan terlebih dahulu melakukan uji normalitas dan uji homogenitas. Pengujian hipotesis dilakukan dengan dua cara yaitu:

1. Uji kesamaan rata-rata pretes (uji $t$ dua pihak)

Uji $\mathrm{t}$ dua pihak digunakan untuk mengetahui kesamaan kemampuan awal siswa pada kedua kelompok sampel. Hipotesis yang di uji berbentuk:

$\mathrm{H}_{0}: \bar{X}_{1}=\bar{X}_{2}$

$\mathrm{H}_{\mathrm{a}}: \bar{X}_{1} \neq \bar{X}_{2}$

Bila data penelitian berdistribusi normal dan homogen maka untuk menguji hipotesis menggunakan uji $\mathrm{t}$ dengan rumus (Sudjana,2005), yaitu:

thitung $=\frac{\bar{X}_{1}-\bar{X}_{2}}{S \sqrt{\frac{1}{n_{1}}+\frac{1}{n_{2}}}}$

dengan $\mathrm{S}$ adalah varians gabungan yang dihitung dengan rumus:

$S^{2}=\frac{\left(n_{1}-1\right) S_{1}^{2}+\left(n_{2}-1\right) S_{2}^{2}}{n_{1}+n_{2}-2}$

Kriteria pengujian adalah : terima $\mathrm{H}_{\mathrm{o}}$ jika $-t_{\left(1-\frac{1}{2} \alpha\right)}<t<t_{(1-1 / 2 \alpha)}$ dimana $t_{1-1 / 2 \alpha}$ didapat dari daftar distribusi t dengan $\mathrm{dk}=\mathrm{n}_{1}+\mathrm{n}_{2}-2$ dan $\alpha=0,05$. Untuk harga t lainnya $\mathrm{H}_{\mathrm{o}}$ ditolak.

2. Uji beda rata-rata postes (Uji t Satu Pihak)

Uji $\mathrm{t}$ satu pihak digunakan untuk mengetahui pengaruh dari suatu perlakuan yaitu Teknik 
Pembelajaran Peta Pikiran (Mind Map) Berbasis Problem Solving terhadap hasil belajar siswa.Pengujian hipotesis dengan uji t dengan rumus:

$$
\mathrm{t}=\frac{\bar{X}_{1}-\bar{X}_{2}}{\sqrt{\frac{S_{1}{ }^{2}}{n_{1}}+\frac{S_{2}{ }^{2}}{n_{2}}}}
$$

dengan $S$ adalah varians gabungan yang dihitung dengan rumus :

$$
S^{2}=\frac{\left(n_{1}-1\right) S_{1}{ }^{2}+\left(n_{2}-1\right) S_{2}{ }^{2}}{n_{1}+n_{2}-2}
$$

\section{HASIL PENELITIAN DAN \\ PEMBAHASAN \\ Hasil Penelitian}

Data nilai pretes dan postes kelas eksperimen yang menggunakan teknik pembelajaran peta pikiran (mind map) berbasis problem solving dan kelas kontrol yang menggunakan model pembelajaran langsung dapat dilihat pada Tabel 1 dan Tabel 2.

Tabel 1. Nilai Pretes Kelas Eksperimen

\begin{tabular}{|c|c|c|c|c|c|c|c|}
\hline \multicolumn{4}{|c|}{ Kelas Eksperimen } & \multicolumn{4}{|c|}{ Kelas Kontrol } \\
\hline Nilai & $\begin{array}{c}\text { Frekuens } \\
\mathrm{i}\end{array}$ & $\begin{array}{l}\text { Rata- } \\
\text { rata }\end{array}$ & $\begin{array}{l}\text { Standar } \\
\text { Deviasi }\end{array}$ & Nilai & $\begin{array}{c}\text { Frekuens } \\
\mathrm{i}\end{array}$ & $\begin{array}{l}\text { Rata- } \\
\text { rata }\end{array}$ & $\begin{array}{l}\text { Standar } \\
\text { Deviasi }\end{array}$ \\
\hline 10 & 1 & \multirow{10}{*}{40,48} & \multirow{10}{*}{12,06} & 5 & 1 & \multirow{10}{*}{42,58} & \multirow{10}{*}{11,39} \\
\hline 20 & 1 & & & 25 & 2 & & \\
\hline 25 & 4 & & & 30 & - & & \\
\hline 30 & 2 & & & 35 & 6 & & \\
\hline 35 & 4 & & & 40 & 6 & & \\
\hline 40 & 3 & & & 45 & 5 & & \\
\hline 45 & 3 & & & 50 & 4 & & \\
\hline 50 & 9 & & & 55 & 6 & & \\
\hline 55 & 4 & & & 60 & 1 & & \\
\hline & $=31$ & & & \multicolumn{2}{|c|}{$\Sigma=31$} & & \\
\hline
\end{tabular}
dan Kelas Kontrol
Tabel 2. Nilai Postes Kelas Eksperimen

\begin{tabular}{|c|c|c|c|c|c|c|c|}
\hline \multicolumn{4}{|c|}{ Kelas Eksperimen } & \multicolumn{4}{|c|}{ Kelas Kontrol } \\
\hline Nilai & Frekuensi & $\begin{array}{l}\text { Rata- } \\
\text { rata }\end{array}$ & $\begin{array}{l}\text { Standar } \\
\text { Deviasi }\end{array}$ & Nilai & $\begin{array}{c}\text { Frekuens } \\
\mathrm{i}\end{array}$ & $\begin{array}{l}\text { Rata- } \\
\text { rata }\end{array}$ & $\begin{array}{l}\text { Standar } \\
\text { Deviasi }\end{array}$ \\
\hline 45 & - & \multirow{10}{*}{75,16} & \multirow{10}{*}{10,99} & 35 & 1 & \multirow{10}{*}{66,13} & \multirow{10}{*}{11,52} \\
\hline 55 & 2 & & & 45 & 3 & & \\
\hline 60 & 4 & & & 55 & 2 & & \\
\hline 65 & 2 & & & 60 & 5 & & \\
\hline 70 & 5 & & & 65 & 7 & & \\
\hline 75 & 2 & & & 70 & 5 & & \\
\hline 80 & 5 & & & 75 & 4 & & \\
\hline 85 & 8 & & & 80 & 3 & & \\
\hline 90 & 3 & & & 85 & 2 & & \\
\hline & $\sum=31$ & & & \multicolumn{2}{|c|}{$\sum=31$} & & \\
\hline
\end{tabular}
dan Kelas Kontrol

Uji normalitas dimaksudkan untuk mengetahui apakah ke dua sampel berdistribusi normal atau tidak. Dari hasil perhitungan uji normalitas diperoleh harga-harga L untuk uji Lilliefors dengan $\alpha=0,05$. Data uji normalitas pada kedua sampel dapat dilihat pada tabel 3 .

\begin{tabular}{|c|c|c|c|c|c|}
\hline $\mathrm{N}_{0}$ & Data & Kelas & $\mathrm{L}_{\text {bitung }}$ & $\mathrm{L}_{\text {tabel }}$ & Kesimpulan \\
\hline \multirow[t]{2}{*}{1} & \multirow{2}{*}{ Pretes } & Eksperimen & 0,1151 & 0,1591 & Normal \\
\hline & & Kontrol & 0,1056 & 0,1591 & Normal \\
\hline \multirow[t]{2}{*}{2} & \multirow{2}{*}{ Postes } & Eksperimen & 0,0965 & 0,1591 & Normal \\
\hline & & Kontrol & 0,0842 & 0,1591 & Normal \\
\hline
\end{tabular}

Tabel 3. Uji Normalitas

Dari tabel 3 diketahui bahwa data pretes dan data postes berdistribusi normal. Hal ini terlihat dari harga Lhitung tidak melebihi Ltabel yang mengindikasikan bahwa data berdistribusi normal.

Uji homogenitas dimaksudkan untuk mengetahui apakah kedua kelas sampel berasal dari populasi yang homogen atau tidak. Maka dilakukan uji homogenitas dengan membandingkan harga $\mathrm{F}_{\text {hitung }}$ dengan $\mathrm{F}_{\text {tabel. }}$ Dimana harga $\mathrm{F}_{\text {tabel }}$ dengan jumlah siswa 31 orang dengan taraf signifikan $10 \%$ adalah 1,84 dan harga $\mathrm{F}_{\text {hitung }}$ adalah 1,21.

Ternyata $\mathrm{F}_{\text {hitung }}>\mathrm{F}_{\text {tabel }}$ hal ini menyatakan bahwa sampel berasal dari 
varians yang sama (homogen). Data uji homogenitas dapat dilihat pada tabel 4 .

Tabel 4. Data Uji homogenitas

\begin{tabular}{|c|c|c|c|c|c|c|}
\hline N0 & Data & Kelas & Varians & $\mathrm{F}_{\text {bitung }}$ & $\mathrm{F}_{\text {tabel }}$ & Kesimpulan \\
\hline \multirow{2}{*}{1} & \multirow{2}{*}{ Pretes } & Eksperimen & 145,4 & \multirow{2}{*}{1,21} & \multirow{2}{*}{1,84} & Homogen \\
\cline { 3 - 4 } & & Kontrol & 129,7 & & & \\
\hline \multirow{2}{*}{2} & \multirow{2}{*}{ Postest } & Eksperimen & 120,78 & \multirow{2}{*}{0,91} & 1,84 & Homogen \\
\cline { 3 - 4 } & & Kontrol & 132,71 & \\
\hline
\end{tabular}

Uji kemampuan awal (data pretes) dilakukan untuk mengetahui apakah kedua kelas sampel dalam penelitian memiliki kemampuan awal yang sama.

Adapun Kriteria pengujian adalah : terima $\mathrm{H}_{0}$ jika $-t_{(1-1 / 2 \alpha)}<t<t_{(1-1 / 2 \alpha)}$ dengan $t_{1-1 / 2^{\alpha}}$ didapat dari daftar distribusi $\mathrm{t}$ dengan $\mathrm{dk}=\mathrm{n}_{1}+\mathrm{n}_{2}-2$ dan $\alpha=0,05$. Untuk harga $\mathrm{t}$ lainnya $\mathrm{H}_{\mathrm{o}}$ ditolak. Data uji kemampuan awal dapat dilihat pada tabel 5

Tabel 5. Data Uji kemampuan awal

\begin{tabular}{|l|c|c|c|c|}
\hline \multicolumn{1}{|c|}{ Data Kelas } & $\begin{array}{c}\text { Nilai } \\
\text { Rata - rata }\end{array}$ & $\mathbf{t}_{\text {bitung }}$ & $\mathrm{t}_{\text {tabel }}$ & Kesimpulan \\
\hline Pretes Eksperimen & 40,48 & \multirow{2}{*}{0,71} & \multirow{2}{*}{2,0} & Terima $\mathrm{H}_{0}$ \\
\hline Pretes Kontrol & 42,58 & & \\
\hline
\end{tabular}

Berdasarkan hasil perhitungan, untuk uji kemampuan awal di peroleh harga thitung $=0,71$ dengan harga $t_{\text {tabel }}=$ 2,00 .

Hasil ini menunjukkan bahwa harga $t_{\text {hitung }}<t_{\text {tabel, }}$ sehingga dapat diperoleh kesimpulan bahwa antara kelas eksperimen dan kelas kontrol mempunyai kemampuan awal yang sama.

\section{Pengujian Hipotesis}

Untuk pengujian hipotesis dilakukan dengan uji beda t satu pihak yaitu membedakan rata-rata hasil belajar siswa kelas eksperimen dan kelas kontrol dengan tujuan untuk mengetahui ada atau tidaknya pengaruh yang signifikan dengan teknik pembelajaran peta pikiran berbasis problem solving terhadap hasil belajar siswa kelas XI SMA Negeri 11
Medan pada materi Fluida Dinamis semester II T.P 2014/2015.

Hasil pengujian hipotesis pada taraf signikan $\alpha=0,05$ dan $\mathrm{dk}=60$, diperoleh $\quad t_{\text {hitung }}=3,20 \quad$ sedangkan $t_{\text {tabel }}=1,67$. Karena $t_{\text {hitung }}>t_{\text {tabel }}$ berarti $H_{a}$ diterima dan $H_{o}$ ditolak, sehingga dapat disimpul-kan ada pengaruh signifikan teknik pembelajaran peta pikiran (mind map) berbasis problem solving terhadap hasil belajar siswa. Secara ringkas hasil perhitungan uji hipotesis dinyatakan dalam tabel 6 .

Tabel 6. Data Uji Hipotesis

\begin{tabular}{|c|c|c|c|c|c|c|}
\hline No & Data & Sampel & Rata-rata & $t_{\text {kimes }}$ & $t_{\text {tabsi }}$ & Kesimpulan \\
\hline \multirow{2}{*}{1.} & \multirow{2}{*}{ Postes } & $\begin{array}{c}\text { Kelas } \\
\text { eksperimen }\end{array}$ & 75,16 & \multirow{2}{*}{3,20} & \multirow{2}{*}{1,67} & $\begin{array}{l}\text { Ada perbedaan } \\
\text { berarti ada } \\
\text { pengaruh }\end{array}$ \\
\cline { 3 - 4 } & Kelas kontrol & 66,13 & & \\
\hline
\end{tabular}

Hasil perhitungan persentase peningkatan hasil belajar siswa pada masing-masing kelas, yaitu kelas eksperimen dan kelas kontrol dapat dilihat pada tabel 7 .

Tabel 7. Hasil Peningkatan Belajar

\begin{tabular}{|l|c|}
\hline \multicolumn{1}{|c|}{ Data } & \% Peningkatan Hasil Belajar (\%g) \\
\hline Kelas Eksperimen & $57 \%$ \\
\hline Kelas Kontrol & $41 \%$ \\
\hline
\end{tabular}

Dari tabel 7 dapat disimpulkan bahwapeningkatan hasil belajar untuk kelas eksperimen yang menggunakan teknik pembelajaran peta pikiran (mind map) berbasis problem solving sebesar $57 \%$ lebih tinggi dari kelas kontrol yang menggunakan model pembelajaran langsung yaitu sebesar $41 \%$.

\section{Pembahasan}

Sebelum diberikan pembelajaran yang berbeda kepada masing-masing kelas terlebih dahulu dilakukan tes awal (pretes) dengan jumlah soal 20 butir dalam bentuk pilihan berganda pada kedua kelas sampel untuk mengetahui kemampuan awal siswa pada materi pokok Fluida Dinamis. Berdasarkan hasil penelitan diperoleh bahwa nilai rata-rata pretes untuk kelas eksperimen yang diajar dengan teknik pembelajaran peta pikiran (mind map) berbasis problem solving sebesar 
40,48 dengan Standar Deviasi sebesar 12,06 sedangkan untuk kelas kontrol yang di ajar dengan pembelajaran langsung adalah 42,58 dengan Standar Deviasi sebesar 11,39. Hasil perhitungan uji normalitas diperoleh Lhitung nilai pretes kelas eksperimen adalah 0,1151 dan Litung nilai pretes kelas kontrol 0,1056 sedangkan harga $\mathrm{L}_{\text {tabel }}$ dengan jumlah siswa 31 sebesar 0,1591. Sesuai dengan kriteria pengujian $\mathrm{L}_{\text {hitung }}<\mathrm{L}_{\text {tabel }}$ maka sampel berdistribusi normal.

Untuk mengetahui bahwa sampel berasal dari populasi yang homogen dilakukan uji homogenitas dengan membandingkan harga $F_{\text {tabel }}$ dengan $\mathrm{F}_{\text {hitung. . Berdasarkan nilai pretes kelas }}$ eksperimen dan kelas kontrol diperoleh $\mathrm{F}_{\text {hitung }}=1,21$ dan nilai postes kelas eksperimen dan kelas kontrol diperoleh $\mathrm{F}_{\text {hitung }}=0,91$ karena $\mathrm{F}_{\text {hitung }}>\mathrm{F}_{\text {tabel }}$ hal ini menunjukkan bahwa bahwa sampel berasal dari populasi yang homogen.

Sedangkan untuk uji kemampuan awal kedua kelas sampel diperoleh harga $t$ untuk thitung $=2,00$ dan $t_{\text {tabel }}=0,71$. Harga $t$ tersebut menunjukkan bahwa Ho diterima yang berarti kedua kelas sampel memiliki kemampuan awal yang sama.

Setelah proses belajar mengajar selesai dengan menerapkan teknik pembelajaran peta pikiran (mind map) berbasis problem solving diperoleh nilai postes pada kelas eksperimen meningkat dengan nilai rata-rata sebesar 75,16 dengan Standar Deviasi sebesar 10,99 dan kelas kontrol sebesar 66,13 dengan Standar Deviasi sebesar 11,52. Hal ini menunjukkan bahwa ada pengaruh penerapan teknik pembelajaran peta pikiran (mind map) berbasis problem solving terhadap hasil pembelajaran.

Hasil uji normalitas diperoleh Lhitungpostes kelas eksperimen adalah 0,0965, Lhitung nilai postes kelas kontrol 0,0842, dimana harga Ltabel dengan jumlah siswa 31 sebesar 0,1591. Sesuai dengan kriteria $\mathrm{L}_{\text {hitung }}<\mathrm{L}_{\text {tabel }}$ maka sampel berdistribusi normal.
Berdasarkan nilai pretes kelas eksperimen dan kelas kontrol diperoleh $F_{\text {hitung }}=1,21$ dan nilai postes kelas eksperimen dan kelas kontrol diperoleh $\mathrm{F}_{\text {hitung }}=0,91$ karena $\mathrm{F}_{\text {hitung }}>\mathrm{F}_{\text {tabel }}$ ini menunjukkan bahwa data penelitian berasal dari populasi yang hoomogen .

Dari perhitungan uji t untuk poste diperoleh nilai thitung $=3,20$ dan $t_{\text {tabel }}=$ 1,67. Nilai distribusi $\mathrm{t} d \mathrm{~d}$ atas menunjukkan harga thitung $>t_{\text {tabel }}$, menolak Ho dan menerima Ha.

Harga uji $t$ menunjukkan bahwa ada pengaruh yang signifikan terhadap hasil belajar siswa dengan penerapan teknik pembelajaran peta pikiran (mind map) berbasis problem solving pada materi Fluida Dinamis Kelas XI Semester II SMA Negeri 11 Medan T.P 2014/2015.

Teknik pembelajaran peta pikiran (mind map) mengadopsi model pembelajaran problem solving, yang mana diketahui bahwa teknik pembelajaran peta pikiran tidak memiliki sintaks pembelajaran, sehingga pada penelitian ini sintaks yang di gunakan adalah model pembelajaran problem solving. Teknik pembelajaran peta pikiran (mind map) berbasis problem solving dapat meningkatkan kemampuan berpikir kritis untuk mencari dan memecahkan sebuah masalah dan dapat meningkatkan kreatifitas siswa. Prinsip pelaksanaan teknik pembelajaran peta pikiran (mind map)ini ialah bagaimana membuat catatan dengan kata kunci teks pada materi dan melengkapinya dengan gambar dan simbol-simbol. Teknik ini melibatkan kesenangan, kreativitas seorang siswa dalam membuat catatan sehingga siswa dapat belajar dengan senang dan lebih mudah memahami serta mengingatnya.

Putra (2008:257) menjelaskan pengertian Mind Map adalah suatu metode pencatatan yang dipopulerkan oleh Tony Buzan, merupakan suatu bentuk pencatatan konvensional. 
Pada dasarnya, tujuan utama penelitian ini adalah untuk mengetahui pengaruh teknik pembelajaran peta pikiran (mind map) berbasis problem solving terhadap hasil belajar siswa.Hasil belajar kelas eksperimen di peroleh dengan nilai rata-rata yang lebih tinggi di bandingkan dengan kelas kontrol. Nilai rata-rata hasil belajar kelas eksperimen telah mencapai kriteria kentutasan minimal (KKM), sedangkan kelas kontrol belum mencapai ketuntasan. Persentase peningkatan hasil belajar kelas eksperimen mencapai $57 \%$ dan kelas kontrol mencapai $41 \%$.

\section{KESIMPULAN DAN SARAN Kesimpulan}

Nilai rata-rata hasil belajar siswa kelas XI semester II SMA Negeri 11 Medan T.P 2014/2015 yang diajar dengan menggunakan Teknik Pembelajaran Peta Pikiran (Mind Map) berbasis Problem Solving pada materi pokok Fluida Dinamis sebesar 75,16. Nilai rata-rata hasil belajar siswa kelas XI semester II SMA Negeri 11 Medan T.P 2014/2015 yang diajar dengan menggunakan Model Pembelajaran Langsung pada materi pokok Fluida Dinamis sebesar 66,13.Ada pengaruh yang signifikan dengan menggunakan teknik pembelajaran peta pikiran (mind map) berbasis problem solving terhadap hasil belajar siswa di kelas XI Semester
II SMA Negeri 11 Medan T.P. 2014/2015.

Saran

Dari penelitian ini disarankan kepada peneliti selanjutnya yang ingin meneliti tentang penerapan teknik pembelajaran peta pikiran (mind map) berbasis problem solving agar memberikan motivasi terlebih dahulu kepada siswa supaya pembelajaran dapat berjalan dengan baik. Mengontrol dan menertibkan siswa yang berdampak pada penggunaan waktu pembelajaran yang efektif.

\section{DAFTAR PUSTAKA}

Buzan, T., (1999), Mind Map. PT

Gramedia Pustaka Utama: Jakarta

Putra, Y., (2008), Memori dan Pembelajaran Efektif, Yrama Widya: Bandung

Saleh, A., (2008), Kreatif Mengajar dengan Mind map, TINTA EMAS Publishing: Bandung

Svantesson, I., (2004), Learning Maps and Memory Skills, PT Gramedia Pustaka Utama: Jakarta

Windura, S., (2009), Be An Absolute Genius! Panduan Praktis Learn How To Learn Sesuai Cara Kerja Alami Otak, PT. Elex Media Komputindo, Jakarta 